\title{
Similarities of External Shock's responses of Armenia and Russia: SVAR Approach
}

\author{
Robert Tumanyan \\ School of Economics and Trade, Hunan University, Yuelushan, Changsha \\ Hunan Province, 410079, People's Republic of China
}

Tel: 86-131-6268-2385Ｅ-mail: robert92tum@gmail.com

Received: December 7, 2017 Accepted: December 21, 2017

doi:10.5296/ber.v8i1.12577～URL: https://doi.org/10.5296/ber.v8i1.12577

\begin{abstract}
The feasibility of EUAE countries to form a Monetary Union is analysed. The paper uses SVAR methodology to examine impact of External Shocks to specific case of Armenia and Russia, alongside with correlation analyses of responses. In this framework, empirical evidence allows to affirm that Armenia and Russia do not meet a criteria of Optimum currency area "similarities in external shock's responses," the results underline structural differences of economies and asymmetry in external shock's responses, therefore EUEA countries are not ready for Monetary union, and deeper integration is needed.
\end{abstract}

Keywords: Structural VAR, Monetary Union, OCA's Theory, EUEA counties

\section{Introduction}

Monetary union in Eurasian Economic Union (EUEA) raises a major interest since 2010, with establishment of custom union among Russia, Belarus and Kazakhstan. In order to promote economic integration in the region early in 2014 EUEA was formulated, in addition to its original members Armenia and Kyrgyzstan also joined the union by signing the treaty. Hence its enlargement and projects for regional economic integration were boosted with single market creation and introduction of the free movement of goods capital and labor, obviously it's not far from projects for monetary union formulation, single currency and deeper integration in the future. As appealing as it could be it is also as uncertain whether EUEA is ready for monetary union and single currency introduction.

This paper seeks to investigate prospective for monetary union between Russia and Armenia as two members with strong economic and political relations. Country-tries have been practicing floating exchange rate regimes and structural difference's in economies are quite noticeable. Monetary union between these two countries illustrates general challenges and 
conditions for monetary union in EUEA. The feasibility of such project requires accomplishment of several requirements and criteria. First MU and criteria for its formation defined by level of integration; in this framework, monetary union is observed as final stage of economic integration. Therefore, followed by economic integration it is essential to accomplish several criteria as it is presented in the theory of Optimal Currency Area, pioneered by Mundel (1961) in this regards (OCA) theory suggest several criteria ${ }^{1}$ for successful currency union. The establishment of a free trade area (FTA), the adoption of a customs union, and the abolition of mobility restrictions of goods, services and production factors. Therefore, following theoretical considerations, a group of countries must achieve three steps before being able to form a Monetary Union. Moreover, the Theory of the Optimal Currency Area (OCA's Theory) establishes several criteria to accomplish by a group of countries.

In this regard, similarities of external shock responses require wider analyses. This paper presents empirical evidence on following issues: I) what are the responses of EUEA economies (in case of Armenia and Russia) to external shocks? Whether responses to external shocks are similar within the member's states? The research follows two steps: First, composition of SVARs model with short runs non-recursive contemporaneous restrictions for both Armenia and Russia, hence responses can be computed. Second, analysis of correlation between same shock responses to measure symmetry of external shocks.

Finally, several noticeable conclusions can be pointed out: SVAR analysis presents vulnerability to commodity price shocks (external supply), both members are highly sensitive to oil price volatility, as well as to Aggregate demand shock (world GDP), on the other hand Armenia and Russia are mostly untouchable to financial volatility (VIX index). Oil price and external demand growth leads to positive growth in GDP meanwhile the increase of financial volatility is observed as recession in growth rate. It is significant that both commodity price and world demands influence asymmetry in CPI and Real exchange rate responses.

In conclusion, this research does not finalize integration in EUEA, but suggests that there are issues on the way for monetary union and single currency insertion, addressed as asymmetric behavior of external shocks to member state's economies.

The research is structured as following: the next section provides theoretical framework and existing literature review on the subject. Section 2 present SVAR and theoretical background, section 3 describes interpretation and results and finally section 4 gives summary of conclusions.

\section{Theoretical Framework and Literature Review}

\subsection{Historical background}

Eurasian Economic Union (EAEU) is a union of countries located in the former Soviet Union. On May 29, 2014, in Astana, the original treaty on the formation of EAEU was signed

\footnotetext{
1 This criterion is important because "if the shocks are symmetric, then it was not necessary to change relative prices between the economies, therefore reducing the cost of giving up exchange rate as adjustment tool (Paolo 2002)
} 
between Belarus, Kazakhstan, and Russia that started its operations on January 1, 2015. Initially, the EEU consisted of Belarus, Kazakhstan, and Russia. Armenia and the Kyrgyz Republic joined on January 2, 2015, and August 12, 2015, respectively. The EAEU represents an integrated single market of 182.7 million people and a gross domestic product (GDP) of over USD 2.2 trillion US estimated in 2014. The EAEU implements the free movement of goods, capital, services, and labor. The common transport, energy, and agriculture policies, with provisions for a single currency and greater integration, are planned in the future. Supranational and intergovernmental institutions manage the union. The Supreme Eurasian Economic Council consists of the heads of the member states. One of the supranational institutions is the Eurasian Commission, which represents the executive body; the others are the Eurasian Intergovernmental Council, which consists of the prime ministers of member countries, and the Court of the EEU, which represents the judicial body.

The formation of the EAEU is structural evolution of different trade agreements and unions between member countries. The groundwork for the EEU was laid immediately after the collapse of the Soviet Union. Several former Soviet countries formed The Commonwealth of Independent States (CIS) in 1991, which was followed by The Treaty on Increased Integration in the Economic and Humanitarian Fields signed in 1996. Soon after, to open economic integration, the Eurasian Economic Community (EurAsEC) was created between Belarus, Kazakhstan, the Kyrgyz Republic, Russia, and Tajikistan. During its existence, the EurAsEC implemented a number of economic policies to unify its community. In 2010, the Custom Union between Belarus, Kazakhstan, and Russia was created. The "four freedoms" (goods, capital, services, and people) were fully implemented by 2012, with the formation of the Common Economic Space or Single Economic Space. In 2015, the EAEU successfully replaced EurAsEC. Currently EEU consists of five member states and aims to bring about changes in services; the labor and financial markets; and macroeconomic, transportation, agricultural, and energy policies. key socio-economic statistic presented in (table 1)

Table 1. Socio-economic statistic

\begin{tabular}{|l|l|l|l|l|l|}
\hline & Armenia & Russia & Kazakhstan & Belarus & Kyrgyzstan \\
\hline Population, total(Mil.) & 3 & 143 & 17 & 17 & 5.8 \\
\hline GDP (Bn.) & 11.16 & 1226 & 225.6 & 166.6 & 13.15 \\
\hline GNI per capita & 4020 & 13220 & 11850 & 7340 & 1250 \\
\hline GDP export & 28 & 30 & 39 & 57 & 37 \\
\hline GDP import & 47 & 23 & 26 & 58 & 88 \\
\hline Inflation, GDP \% & 2.7 & 7.2 & 6.0 & 18.1 & 7.9 \\
\hline
\end{tabular}

Source: IMF, IFS statistic

For this research, a wide range of literature has been studied beginning with initial theory of economic integration Jacob Viner 1950 and summarized by Hungarian economist Ballesa in late $60 \mathrm{~s}$, which was broadly used in European economic integration. Theoretical framework of European economic integrations is well presented by Francesco Paolo Mongelli (2008) ECB representative and summarizes key points of monetary integration formerly studied by W. Max Corden in 90s, according to Vinner's key stages of integration are preferable trading 
area creation alongside with customs union followed by monetary union and single currency insertion, however these stages are not consequent, according to modern researchers economic integration is mostly unique phenomenon and has various specialties based of level of integration, objectives and its members. An important paper utilized in this re- search is form Salif Kone (2012) where author describes integration and singular and continuous process that take place in multiple dimensions such as socio-economic, financial and cultural. Alongside with European integration similar projects in other regions with their own challenges and differences have been observed particularly West African monetary union as a successful attempt to create monetary union but fail in other stages of integration. Sisira Jayusiriya, Nephil Mantagi (2005) discusses issues of south Asian economic union and monetary integration in particular observe questions concerning single currency integration testified with OCA criteria and shocks analysis methodology. Advantages of single currency by Mishkin and Calvo (2003) deeply discus synchronized shocks for developing countries.

\subsection{Optimum Currency Area (OCA) Theory}

OCA defines an optimum currency area By Paolo (2002) as the optimal region of a single currency, whose exchange rates is strongly pegged and might be shared as a single currency. The single currency, or the pegged currencies, can fluctuate only against the rest of the world. The optimality of the area is defined as following:

- High level of trade in goods

- Labor mobility across members

- Financial markets integrated

- $\quad$ Price and wage flexibility

- Diversified composition of output and trade across countries

- Similar inflation rates

- Absence of fiscal dominance in the individual countries

- Similarity of external shocks to which the different courtiers are exposed

- Political coordination between countries

The achievement these criteria reduces the usefulness of nominal exchange rate adjustments within the currency area adjusting internal and external balance, reducing the impact of similar shocks. These criteria are "pre-required" in order to achieve formulation of a successful and effective monetary union.

This paper is focused on similarities of shock responses which is essential for OCA theory according to most researcher's symmetry in shocks gives a fundamental analyze whether the region is ready for Monetary union and what are challenges and barriers ${ }^{2}$. Therefore, a deep research is required applying relevant econometric approaches. The empirical studies in

\footnotetext{
${ }^{2}$ See Paolo (2002), Mundell (1973)
} 
regards of OCA's criteria develop by 1980 thanks to the advancements in econometric techniques and the researches provided by the European experience.

\subsection{Shock Similarity}

The $\mathrm{SVAR}^{3}$ approach has been widely used and remains most popular technique to measure Asymmetric shocks across countries, as a result of its suitability to identify aggregate supply and demand shocks and distinguish them from subsequent policy responses. Even though other techniques have been offered such as: Bivariate auto-regressions, stochastic simulations using macroeconomic models, meanwhile the Vector Auto-regression models remain the most used one. Therefore, this research work applies on the following contribution.

The framework proposed by Gali (1992) provided guidelines to analyze shocks and measure shocks and their individual relative importance, as well as, to interpret some macroeconomic scenarios, study sources of permanent shocks to nominal variables.

Gimet (2007) applied individual SVARs models to deal with the reasons that led the Mercosur countries to let their currency float at the end of the nineties. Author states, by analyzing vulnerability to shocks, that there is a lack of sustainability of the exchange rate regimes.in addition, following Bayoumi and Eichengreen (1993) and Canova (2003) methodology, also measures the similarities of shocks impacts by studying the correlations of responses between countries. The results proved that there is similarity of reactions to shocks within the bloc.

In this research behavior of each individual shock is examined and described by shock response indicators, methodology is implied and selected by literature mentioned above, shock symmetry correlation amylase is inspired by Gimet (2007) and Bolanos (2011) variables are selected according to examined literature and relevance for Russian and Armenian economies as main driving forces. Such analytics breaks down if OCA criteria is testified and could be applied for rest of EUEA members, moreover a study of Russia and Armenia case can drive to conclusion, whether EUEA in general, is suitable for monetary union, as Russia and Armenia representing biggest and smallest economies of region with strong economic and political ties.

\subsection{Econometric Framework and SVAR Methodology}

A common practiced approach to identify the nature and impacts of macroeconomic shocks is the structural vector auto-regression (SVAR) model, which helps determine interconnections and endogeneity. SVAR models applied as an approach in which all variables can, in general, be affected by each other, helping capture interdependence. The paper's uses SVAR model that estimates the impact of global shocks on Armenian and Russian key macroeconomic variables such as GDP growth, CPI rates, money market volatility and RER real effective exchange rate fluctuations. Following Chowla, Quaglietti and Rachel (2014), SVAR includes various kinds of shocks, this papers presets them as world demand shocks, which are

\footnotetext{
${ }^{3}$ Since the Sims (1980), Shapiro and Watson (1988) and Blanchard and Quah (1989), the Vector Autoregresion Models (VARs), particularly Structural ones (SVARs), have been defined as the most feasible methodology to estimate shocks impacts into economy
} 
represented by changes in the growth rate of an indicator of world GDP; oil price shock, which are given by changes of international commodity prices, world financial shocks, represented by changes in international financial conditions The SVAR imposes structure on the data, which helps trace shock impacts on Armenian and Russian GDP growth, CPI changes , Real exchange rate and money market rates. Following Blanchard and Quah (1989), the variables included in the SVAR are ordered by Choleski decomposition, and can be expressed as following.

$$
\left.Z=\left(d Y_{t}^{\text {world }}, d P_{t}^{\text {worl }}, d F_{t}^{\text {woldr }}\right) d Y^{i}{ }_{t}, d C P I_{t}^{i}, d R E R_{t}^{i}, d R_{t}^{i}\right)
$$

Where $P_{t}^{\text {worl }}$ is for crude oil price in the world, $Y_{t}^{\text {world }}$ is world aggregate GDP, $F_{t}^{\text {wold }}$ is VIX index. Respectively, $Y_{t}^{i}$ stands for GDP growth for Armenia and Russia $C P I_{t}^{i}$ is CPI index ( consumer price index), $R E R_{t}^{i}$, is Real exchange rate and Money market rate for Armenia and Russia consequently. In this framework external shocks are presented as commodity price, world GDP and financial volatility shocks. Hence SVAR methodology doesn't identify shocks applying Choleski decomposition each external shock is observed separately from another and presented as response function to endogenous variables.

\subsection{Empirical Formulation}

This research seeks to investigate the following questions: I) what are responses of Armenia and Russia to external shocks, II) Whether responses are symmetric between Russia and Armenia to same external shocks? In order to answer the mentioned above three SVAR models for both Armenia and Russia have been constructed each presenting one particular external shock and its impact of macroeconomic variables that have been chosen. In addition, the responses for same external shocks regarding impact on same macroeconomic variable are correlated and presented as coefficient of correlation.

\subsection{Data}

The estimations are done using two sets of variables. The data set contains real GDP growth rate, CPI changes, RER- real effective exchange rate, and money market rate, a world commodity price index (given by the IMF's crude oil prices index), and an indicator of international financial market conditions (given by the VIX, which measures investor risk aversion). It includes as well aggregated world real GDP growth rate. The data is quarterly for 2000Q1 to 2016Q1. Armenian time series have been obtained from Central Bank of Armenia and National Statistical Service of Armenia. World and regional data have been taken from IFS statistic and World Bank, Russian data have been collected from the Federal State Statistics Service of the Russian Federation, IMF and Eurostat.

All variables were transformed in logarithms except for the domestic money market rates and they were seasonally adjusted. Detailed date is with economic indicators are described in annex 1

\section{Econometric Results}

Results displayed in Annex 2. And illustrate the responses of domestic variables to a standard deviation variation (SDV) of the external variables. Error bands for Impulse Responses are 
computed with the Asymptotic Method, and Impulse Response graphs contain the plus/minus two standard error bands about the impulse responses. A response is significant if its computed error band do not include the zero. The following is a short-term analysis: the responses correspond to differentiated variables and the imposed restriction, for non-restricted ones those are the short ones.

\subsection{Oil Price Shock}

As it has been suggested previously, Russian and Armenian economies are heavily relying on oil price level and commodity price level. In the period of 2000 to 2016, since Russia is mainly oil exporter and Armenia is commodity exporter; therefore, crude oil price (international trade shock) affects directly their GDP. Oil price rise and net exports of commodities producers rise also, increasing aggregate demand and consequently production and level prices augment (AD-AS model theory). Changes in interest and exchange rates will depend on each country's monetary policy objective and exchange rate regime.

Exports of commodities rises production prices simultaneously, increasing aggregate demand and consequently production. Which leads to price level augmenting (AD-AS model theory). Changes in interest and exchange rates depending on each country's monetary policy objective and exchange rate regimen.

As it shown in (table2) from 2000 to 2016 Armenian GDP $Y^{\text {ARM }}$ and Russian GDP $\mathrm{Y}^{\text {RUS }}$ respond positively and significantly to the shock, as a result standard deviation variation (SDV) of oil price changes, 1 percent point increase stimulates 1.55 percentage point of GDP growth in Armenia and 0.75 percent growth after first quarter for Russia and reaches its peak by 0.92 at second quarter. The results bring out that Russia is mainly an oil export country and with higher oil price level higher demand is accelerated, and on the other hand since Armenia being an oil importer which seem to have inverse effect but the positive effect itself is generated by Russian GDP growth, therefore remittances from Russia and finally increase in commodity prices should stimulate Armenian mining export.

Armenia's prices level $\mathrm{CPI}^{\mathrm{ARM}}$ changes in fluctuation generated by oil prices shock is 0.22 and 0.36 percent after first two quarters and changes its direction to negative sign after second. That is explained by Armenia being heavily in need of oil import and hence, CPI can be explained by higher prices on oil imports. Meanwhile, Russia remains relatively stable in terms of CPI with negative sign 0.07 and 0.16 decrease in CPI changes negatively, explained by gradual appreciation of Ruble hence favorable prices for import, also higher prices for oil generate higher demand in local markets therefore Russian CPI decreases. Russian Real exchange rate is significantly influenced by Oil prices with positive sign and 1.56 percent point appreciation after first quarter. In contrast, Armenian RER depreciated with negative sign and by 0.52 point after first quarter followed by appreciation after second but deprecates after fifth quarter consequently. Oil price fluctuation in regards of Oil price rise positively affected Russian terms of trade promoting higher volume of export, in contrast higher oil prices for Armenia is followed with negative terms of trade, since import increases. Money market rates are relatively untouched by Oil price shocks but absorbed with negative sign in their vector, both for Russia and Armenia. 


\section{Al Macrothink}

Business and Economic Research

ISSN 2162-4860

2018, Vol. 8, No. 1

Table 2. Oil price shock responses to Armenia and Russia

\begin{tabular}{|l|l|l|l|l|l|l|l|l|l|}
\hline \multicolumn{4}{|l|}{ Variables responses to oil price shock in Armenia } & \multicolumn{4}{|l|}{ Variables responses to oil price shock in Russia } \\
\hline Period & Y_RUS & CPI_RUS & RER_RUS & R_RUS & Period & Y_ARM & CPI_ARM & RER_ARM & R_ARM \\
\hline Q1 & 0.7529 & -0.0728 & 1.5688 & -0.1720 & Q1 & 1.5504 & 0.2208 & -0.5237 & -0.2487 \\
\hline Q2 & 0.9225 & -0.1616 & 1.0167 & -0.3929 & Q2 & 1.4135 & 0.3696 & 0.1097 & -0.2692 \\
\hline Q3 & 0.2735 & -0.0363 & 0.4807 & -0.2611 & Q3 & 0.2044 & -0.3096 & 1.0341 & -0.1024 \\
\hline Q4 & -0.0006 & 0.1070 & 0.6150 & -0.1618 & Q4 & -0.1488 & -0.1141 & 0.8479 & -0.0588 \\
\hline Q5 & 0.0989 & 0.0604 & 0.5206 & -0.1547 & Q5 & 0.0450 & -0.0406 & 0.2184 & -0.0696 \\
\hline Q6 & 0.1177 & 0.0114 & 0.2616 & -0.1234 & Q6 & 0.1044 & -0.0044 & -0.0228 & -0.0683 \\
\hline Q7 & 0.0328 & 0.0143 & 0.1807 & -0.0768 & Q7 & 0.0789 & -0.0019 & 0.0396 & -0.0527 \\
\hline Q8 & -0.0006 & 0.0181 & 0.1471 & -0.0496 & Q8 & 0.0331 & 0.0055 & 0.0966 & -0.0403 \\
\hline Q9 & 0.0107 & 0.0082 & 0.0914 & -0.0381 & Q9 & 0.0181 & 0.0005 & 0.0837 & -0.0328 \\
\hline Q10 & 0.0115 & -0.0001 & 0.0515 & -0.0277 & Q10 & 0.0096 & -0.0011 & 0.0514 & -0.0276 \\
\hline Q11 & 0.0023 & -0.0017 & 0.0334 & -0.0181 & Q11 & 0.0092 & 0.0002 & 0.0317 & -0.0234 \\
\hline Q12 & -0.0008 & -0.0019 & 0.0223 & -0.0125 & Q12 & 0.0082 & 0.0023 & 0.0238 & -0.0198 \\
\hline
\end{tabular}

Source, authors calculations

\subsection{World Demand Shock}

Global demand shocks also have a significant influence on Armenian and Russian economic growth, and as its presented in table 3 a SDA shock of global demand growth stimulates 1.1 percentage point increase in Armenian economic growth after the first quarter. Although the initial impact of global demand shocks is initially small this reflects the spillovers through trade, remittance, tourism, and FDI, and bank linkages, from stronger (or weaker) growth in Russia, which are Armenia's key trading partners and main sources of remittances and FDI. Armenia CPI is relatively unchanged by world GDP growth only 0.1 after first quarter, same behavior is observed for Armenian Real exchange rates and interest rate with 0.12 and 0.03 representable.

For Russia, Global demand growth is also highly influential in term of economic growth, a SDA shock leads to a 0,57 percent after first quarter, which is explained by higher demand for Russian export. The overall impact on CPI is insignificant with negative direction, on the other hand it's notable that Russian Real exchange rate is significantly influenced by world GDP growth higher world demand stimulated Russian export, which promotes Russian terms of trade. Money market in Russia as in Armenia is not volatile to demand shocks. Results are presented in (table 3) 
Table 3. World demand (GDP growth) shocks in Russia and Armenia

\begin{tabular}{|l|l|l|l|l|l|l|l|l|l|}
\hline \multicolumn{4}{|l|}{ Variables responses to World demand in Russia } & \multicolumn{4}{|l|}{ Variables responses to World demand in Armenia } \\
\hline Period & Y_RUS & CPI_RUS & RER_RUS & R_RUS & Period & Y_ARM & CPI_ARM & RER_ARM & R_ARM \\
\hline Q1 & 0.5724 & -0.0759 & 1.1162 & -0.1410 & Q1 & 1.1064 & 0.1107 & 0.1208 & 0.0381 \\
\hline Q2 & 0.5108 & -0.1491 & 0.4313 & -0.2102 & Q2 & 0.5141 & 0.1309 & 0.9523 & -0.0129 \\
\hline Q3 & 0.2547 & 0.0409 & 0.1553 & -0.1551 & Q3 & 0.3825 & -0.0132 & 1.0069 & -0.0103 \\
\hline Q4 & 0.1465 & 0.1207 & 0.3760 & -0.1435 & Q4 & 0.1469 & 0.0312 & 0.5908 & -0.0059 \\
\hline Q5 & 0.1184 & 0.1274 & 0.1891 & -0.1138 & Q5 & 0.1045 & 0.0138 & 0.1698 & 0.0092 \\
\hline Q6 & 0.0680 & 0.1292 & 0.1770 & -0.0695 & Q6 & -0.0238 & 0.0163 & -0.1016 & 0.0303 \\
\hline Q7 & 0.0173 & 0.0992 & 0.2503 & -0.0315 & Q7 & -0.0831 & -0.0130 & -0.2175 & 0.0484 \\
\hline Q8 & -0.0198 & 0.0615 & 0.1896 & -0.0026 & Q8 & -0.1193 & -0.0227 & -0.2422 & 0.0554 \\
\hline Q9 & -0.0408 & 0.0319 & 0.1154 & 0.0145 & Q9 & -0.0946 & -0.0277 & -0.2080 & 0.0517 \\
\hline Q10 & -0.0431 & 0.0075 & 0.0583 & 0.0202 & Q10 & -0.0576 & -0.0205 & -0.1432 & 0.0414 \\
\hline Q11 & -0.0336 & -0.0074 & 0.0008 & 0.0188 & Q11 & -0.0170 & -0.0136 & -0.0700 & 0.0295 \\
\hline Q12 & -0.0203 & -0.0120 & -0.0330 & 0.0138 & Q12 & 0.0085 & -0.0065 & -0.0104 & 0.0190 \\
\hline
\end{tabular}

Source, authors calculations

\subsection{Financial Volatility}

Financial shock is not influential over both Armenian and Russian economies, the initial effect is almost zero but the impact gradually becomes noticeable over time. Results are presented in Table 4 A SDA shock to VIX index, Armenia's GDP growth is affected negatively and declines by -0.018 after the first quarter. CPI is also affected negatively and not significantly; Real exchange rate and interest rates are positively influenced but also as mentioned are not significant. For Russia, same situation is observed with a SDA to VIX Russia's GDP growth declines by -0.04 percent point. And it's also insignificant for CPI, Real exchange rate and interest rates. Financial conditions insignificance breaks down by low level of financial integration observed for Russia and Armenia. Results presented in (table4)

Table 4. VIX shock in Armenia and Russia

\begin{tabular}{|l|l|l|l|l|l|l|l|l|l|}
\hline \multicolumn{4}{|l|}{ Variables responses to VIX shock in Armenia } & \multicolumn{5}{|l|}{ Variables responses to VIX shock in Russia } \\
\hline Period & Y_ARM & CPI_ARM & RER_ARM & R_ARM & Period & Y_RUS & CPI_RUS & RER_RUS & R_RUS \\
\hline Q1 & -0.0108 & -0.0029 & 0.0049 & 0.0011 & Q1 & -0.0049 & -0.0005 & -0.0095 & 0.0015 \\
\hline Q2 & -0.0116 & 0.0004 & -0.0030 & 0.0019 & Q2 & -0.0050 & 0.0019 & -0.0154 & 0.0019 \\
\hline Q3 & -0.0015 & 0.0027 & -0.0089 & 0.0004 & Q3 & -0.0006 & 0.0007 & 0.0010 & 0.0012 \\
\hline Q4 & 0.0026 & 0.0007 & -0.0063 & 0.0005 & Q4 & 0.0003 & -0.0010 & -0.0011 & 0.0008 \\
\hline Q5 & 0.0001 & 0.0006 & -0.0007 & 0.0007 & Q5 & -0.0006 & -0.0002 & -0.0039 & 0.0009 \\
\hline Q6 & -0.0001 & -0.0001 & 0.0009 & 0.0006 & Q6 & -0.0005 & 0.0002 & -0.0009 & 0.0006 \\
\hline Q7 & -0.0003 & -0.0002 & 0.0001 & 0.0005 & Q7 & 0.0000 & -0.0001 & -0.0004 & 0.0004 \\
\hline Q8 & 0.0001 & -0.0002 & -0.0004 & 0.0004 & Q8 & 0.0000 & -0.0001 & -0.0008 & 0.0003 \\
\hline Q9 & 0.0000 & -0.0001 & -0.0005 & 0.0004 & Q9 & -0.0001 & 0.0000 & -0.0004 & 0.0002 \\
\hline Q10 & 0.0001 & 0.0000 & -0.0003 & 0.0003 & Q10 & 0.0000 & 0.0000 & -0.0002 & 0.0002 \\
\hline Q11 & 0.0000 & 0.0000 & -0.0002 & 0.0003 & Q11 & 0.0000 & 0.0000 & -0.0002 & 0.0001 \\
\hline Q12 & 0.0000 & -0.0001 & -0.0002 & 0.0002 & Q12 & 0.0000 & 0.0000 & -0.0001 & 0.0001 \\
\hline
\end{tabular}

Source, authors calculations

\subsection{External Shocks Correlation Analyses}

To measure the symmetry in the responses of Armenia and Russia to external shocks, inspired 
by Gimet (2007), the correlation analysis of countries' significant responses has been calculated and presented as correlation coefficients. In order to understand whether EUEA members- Armenia and Russia are fulfilled with one OCA's criteria8 "Similarity (synchronization) of external shocks to which the different countries are exposed to" results presented in (table 5)

Table 5. Correlation of external shock responses

\begin{tabular}{|l|l|l|l|l|}
\hline & Oil & VIX & Y & Average \\
\hline Y & 0.87 & 0.89 & 0.84 & 0.87 \\
\hline CPI & $(0.66)$ & 0.31 & $(0.77)$ & $(0.37)$ \\
\hline REER & $(0.18)$ & $(0.21)$ & $(0.31)$ & $(0.23)$ \\
\hline R & 0.81 & 0.87 & $(0.04)$ & 0.55 \\
\hline Average & 0.21 & 0.47 & $(0.07)$ & 0.20 \\
\hline
\end{tabular}

Source: Authors' calculations

As the theory suggests, the symmetry is expected between the member's responses to shocks for efficient monetary union. Annex 2 illustrates the found results. In general Correlations of responses between Russia and Armenia indicate statistical significance ( 0.5 and over) in period of 2000 to 2016 for Oil price shock to domestic variables the findings suggest a strong correlation between GDP growth with coefficient of 0.87 meanwhile the negative correlation with -0.66 coefficients is observed for CPI and -0.18 for Real exchange rate on the other hand, money market rates responses are correlated with 0.81 coif. World demand shock presented via world GDP growth underline strong correlation between countries' GDP growth responses with 0.89 coefficients. Meanwhile CPI is in negative correlation with -0.77 , Real exchange rate is also negative $-0,31$ and Interest rates are insignificant. Financial stability shock represented as VIX shock demonstrates symmetry of responses between Armenia and Russia but as it has been mention in previous section VIX shocks are overall insignificant. To conclude the asymmetry in Real exchange rate and CPI responses highlight general asymmetry in external shocks responses, moreover GDP growth in Armenia after Oil price shock is generated by current exchange rate policy and if Armenia would practice fixed exchange rate with Russia the effect after all will lead to GDP decrease which is break down main conclusion that external shocks behavior is Asymmetric.

Finally, I cannot conclude that Armenia and Russia achieve Similarity of external shocks to which the different countries are exposed to criteria; the results underline major differences in economies' structures and different terms of trade.

\section{Conclusion}

Using a SVAR model, this paper examines the impact of external shocks to Armenian and Russian economies, in order to analyse whether Armenia and Russia are ready for Monetary Union. Theoretical background is based on Optimum currency area theory; hence it is important to examine external shock's responses and its correlation (symmetry). Results show that the impact of Oil price, and global demand shock is highly significant both for Armenian and Russian economies, a positive Oil price shocks stimulates GDP growth in Russia 
securing a positive term of trade and through remittances the GDP growth transformed to Armenia. On the other hand, negative terms of trade are observed in Armenia. A positive oil price effect appreciates Russian real exchange rate due to positive trade balance, in contrast Armenian exchange rate falls to deprecation, which increases global remittances, therefore stimulates GDP growth after positive oil price shock.

The correlation analyses lead to following conclusions first GDP growth rates are highly correlated but a negative correlation (asymmetry) is observed in Real exchange rate and CPI correlation analyses, therefore it can be concluded external shocks responses are asymmetric since with pegging Armenian and Russian exchange rate regimes Armenia will no longer be able to transform Oil price shocks to positive effect on GDP growth.

Finally, the research suggests that Armenia and Russia respond to shocks differently, hence a MU is not feasible without minimizing structural differences in economies. It can be suggested that deeper and continuous economic integration is needed in EUEA alongside with bilateral trade promotion, financial integration, single market for goods and services. Since economies are strongly influenced by oil prices a single energy market could minimize the structural differences mentioned before, making a step forward Monetary Union.

\section{References}

Balassa, B. (1961). The Theory of Economic Integration: An Introduction. The Theory of Economic Integration, 173-183. http://ieie.itam.mx/Alumnos2008/Theory of Economic Integration (Belassa).pdf

Bayoumi, T., Eichengreen, B., \& Mauro, P. (2000). On Regional Monetary Arrangements for ASEAN. Journal of the Japanese and International Economies, 14, 121-148.

https://doi.org/10.1006/jjie.2000.0446

Blanchard, O. J., \& Quah, D. (1989). The Dynamic Effects of Aggregate Demand and Supply Disturbances. National Bureau of Economic Research Working Paper Series, No. 2737. http://www.jstor.org/stable/1827924

Cooke, D. (2012). Federal Reserve Bank of Dallas Globalization and Monetary Policy Institute. 0-25.

IMF. (1997). Indonesian Measures Welcomed as Important Step In Stabilizing Southeast Asian Financial Markets. Imf, 26.

Jayaraman, T. K. (2005). A Single Currency For Pacific Island Countries: An Svar Analysis A Single Currency For Pacific Island Countries.

Kim, S., \& Roubini, N. (2000). Exchange rate anomalies in the industrial countries: A solution with a structural VAR approach. Journal of Monetary Economics, 45, 561-586. https://doi.org/10.1016/S0304-3932(00)00010-6

Knarik, Ayvazyan, T. D. (2015). Spillovers from Global and Regional Shocks to Armenia. International MonetaryFund.

https://www.imf.org/ /media/Websites/IMF/imported-full-text-pdf/external/pubs/ft/wp/2015/ 
_wp15241.ashx

Mongelli, F. P. (2002). "New" views on the optimum currency area theory: What is EMU telling us? EZB Working Paper Series, 1-53.

Sato, K., Zhang, Z., \& McAleer, M. (2011). Identifying shocks in regionally integrated East Asian economies with structural VAR and block exogeneity. Mathematics and Computers in Simulation, 81, 1353-1364. https://doi.org/10.1016/j.matcom.2010.06.009

\section{Annex}

Annex1 Economic indicators

GDP growth time series

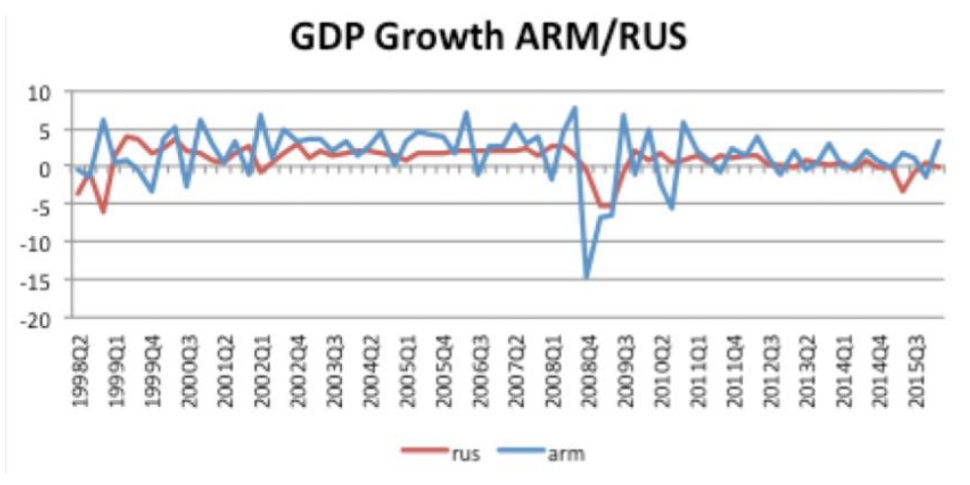

Source: IMF, IFS statistics

CPI time series

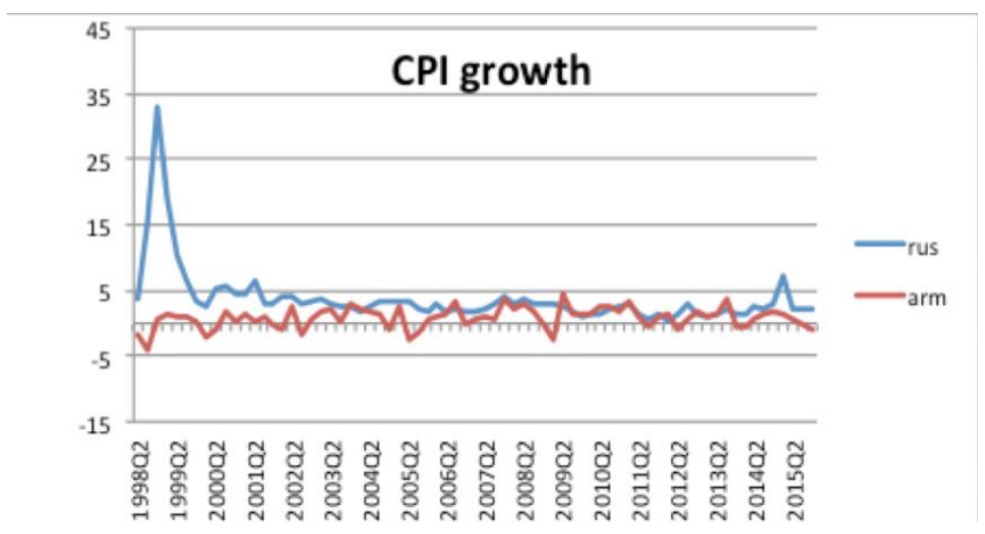

Source: IMF, IFS statistics 
Terms of trade

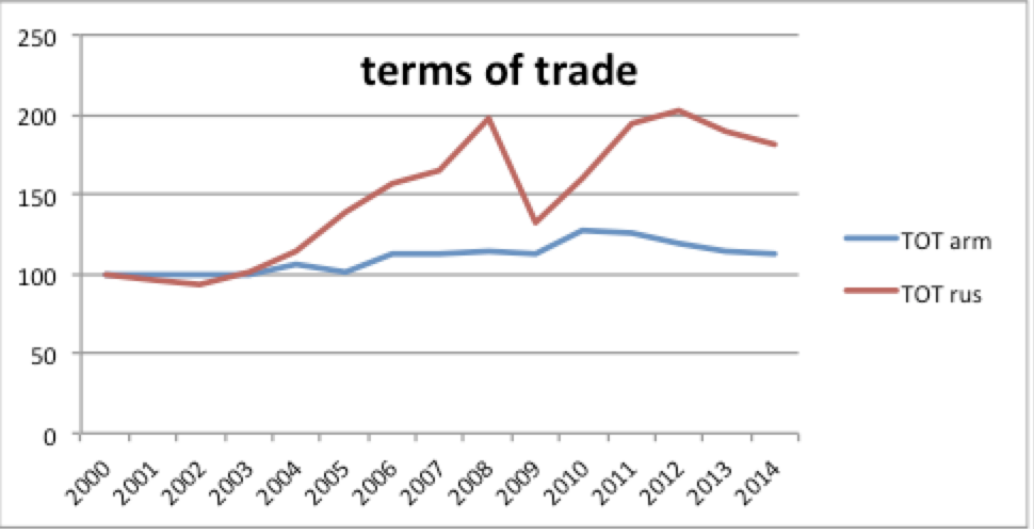

Source: IMF, IFS statistics

Openness

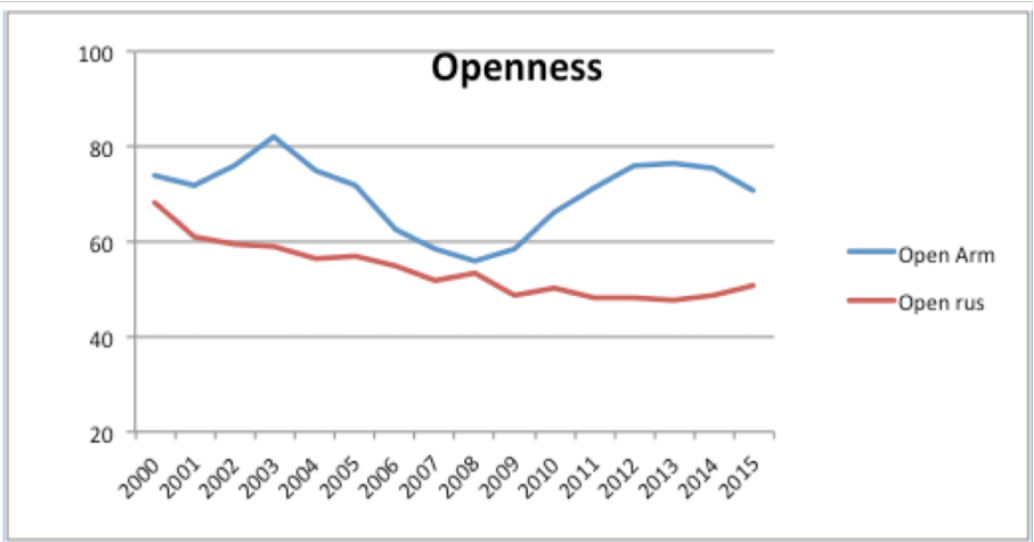

Source: IMF, IFS statistics 2000=100 Real exchange rate time series GDP growth time series

\section{Annex 2}

Shock responses oil price

Response to Cholesky One S.D. Innovations \pm 2 S.E
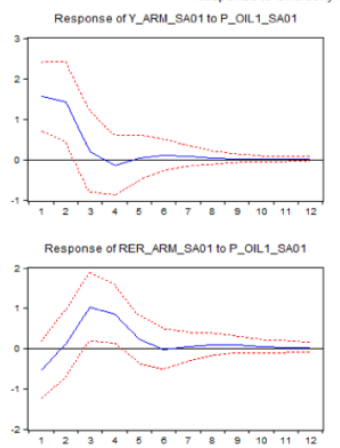

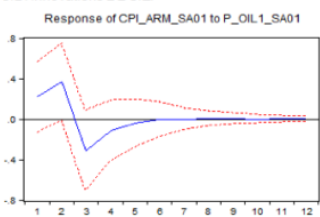

Response OtR_AR01 10 P_OOLI_SAO

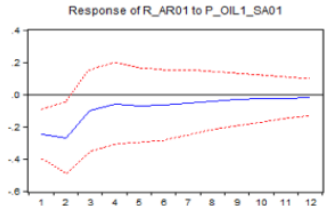

Response to Cholesky One S.D. Innovations \pm 2 S.E.

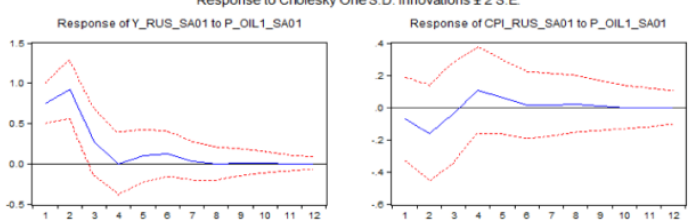

Response of R_RUSSIM01 to P_OLL1_SAOP

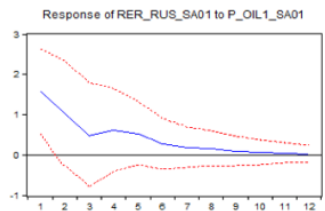


world demand GDP growth
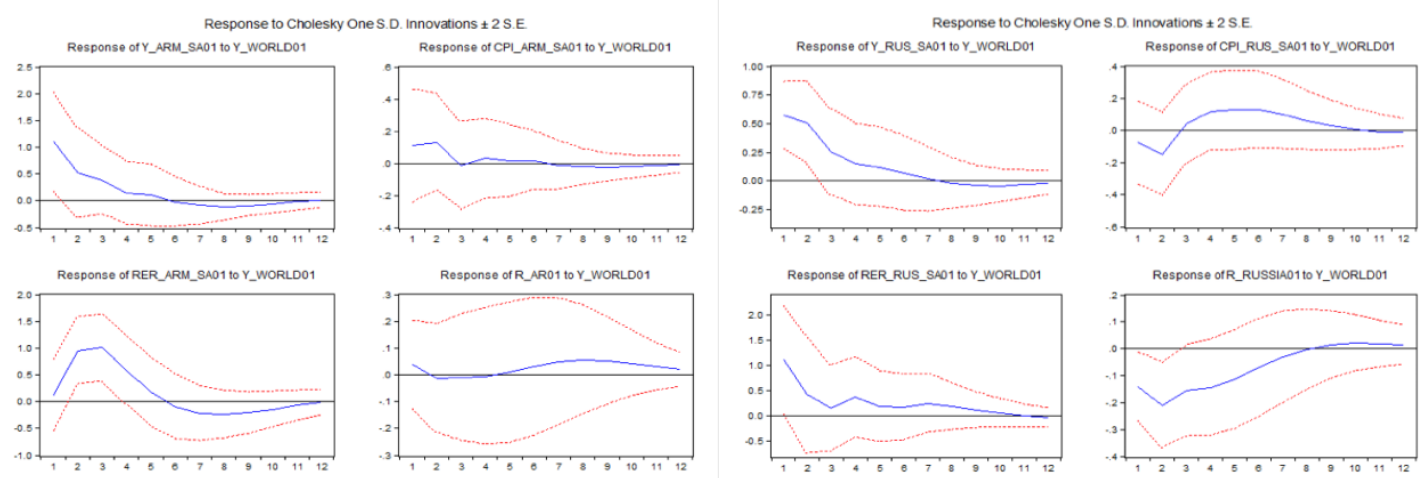

Armenia

Russia

VIX shock
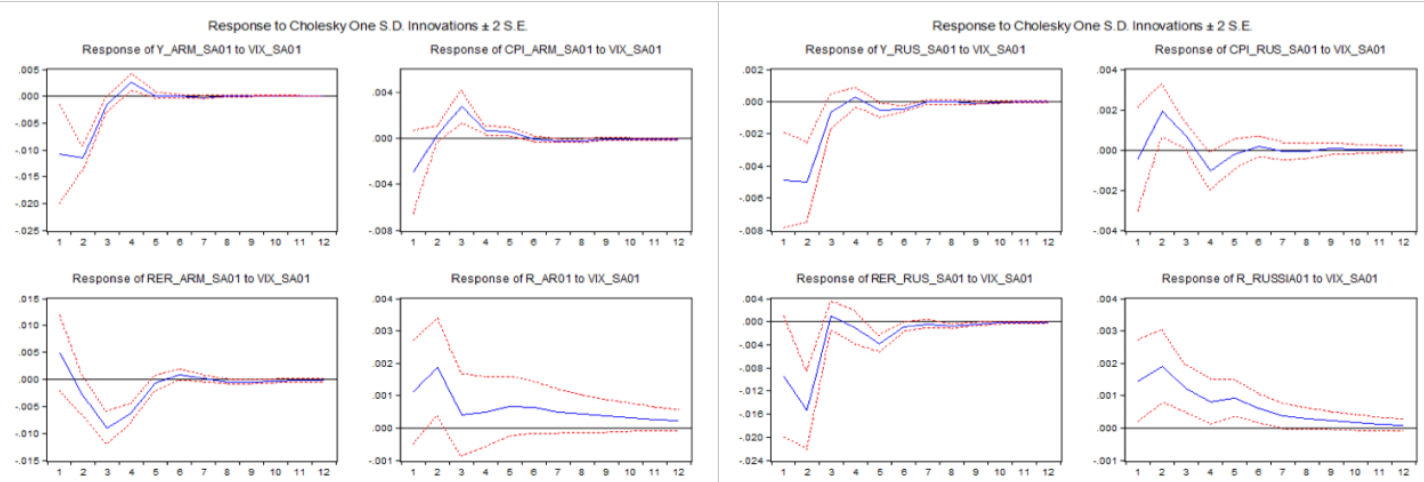

Armenia

Russia

\section{Copyright Disclaimer}

Copyright for this article is retained by the author(s), with first publication rights granted to the journal.

This is an open-access article distributed under the terms and conditions of the Creative Commons Attribution license (http://creativecommons.org/licenses/by/3.0/). 